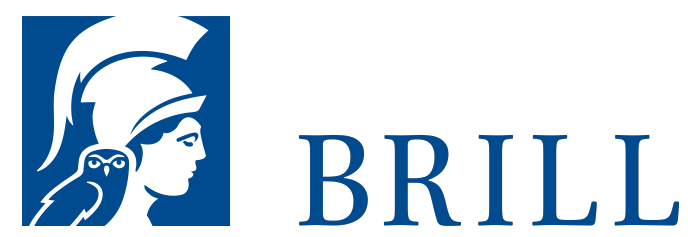

\title{
Recherches sur le recensement dans l'Egypte romaine
}

Author: Hombert

Language:

French

Subjects:

General,

Classical Studies

Publisher: Brill

Series:

Papyrologica

Lugduno-

Batava, Volume:

5

E-Book (PDF)

Released online: $\mathrm{O} 2 \mathrm{Mar} 2 \mathrm{O} 2 \mathrm{O}$

ISBN: 978-90-

O4-42995-6

List price

USD $\$ 42.00$

Hardback

Publication date:

o1 Dec 1952

ISBN: 978-90-

04-4288o-5 
For more information see brill.com

Order information: Order online at brill.com +44330 333 0049 | customerservices@brill.com Submission information: brill.com/authors

Titles published by Brill | Fink, Brill | mentis or Brill | Schöningh: +49(o)715413279216| brill@brocom.de 